\title{
Raúl Antelo
}

Desastre e disparate

Religion du salut par l'image, le christianisme s'est vu dépossédé au $19^{\text {e }}$ siècle de sa capacité à donner un contenu spirituel à l'histoire. Restait l'art, qui devint la matrice de l'histoire: l'image ne projetait plus un avenir homologue au passé dont elle témoignait, elle devenait capable de produire un avenir sans précédent. Notre siècle est l'héritier des Romantiques, qui firent de l'artiste un prophète et donnèrent à l'image ce pouvoir de façonner l'histoire, au risque que cette puissance nouvelle soit au service des totalitarismes.*

A prevenção de Éric Michaud com relação aos desvios totalitaristas, populistas ou simplesmente de massas, gerados pela imagem, prevenção presente também, por exemplo, em "Déjà là mais encore à venir. Le temps de l'homme nouveau en Allemagne 19181945 ", texto que, a pedido de Jean Clair, ele redige para a exposição Les années 1930: La fabrique de "L’homme nouveau"(Musée des Beaux Arts du Canada, 2008) revela as limitações que uma compreensão autonomista da arte ainda mantém com relação às imagens. Michaud, com efeito, nem sempre consegue, em sua análise, tirar todas as consequências de, por exemplo, Henri Bergson ter percebido, já nos anos 20 , que a arte buscava imprimir em nós sentimentos muito profundos e não exatamente exprimi-los, o que ainda pressuporia uma dócil imitação da natureza. Apreensivo e cauteloso ante essas faculdades hápticas do visual, Michaud tenta disciplinar os usos da imagem, porque

En se déprenant peu à peu de la figuration des corps, ou de "l'imitation de la nature", l'image ne prend plus sens d'un passé auquel elle redonne la présence, mais produit son propre sens par et dans le spectateur à venir.

Nesse sentido, recrimina a Carl Einstein que veja, na arte, uma força que atiça a irracionalidade do espectador, um perigoso meio mágico de reintegrar o mito à realidade. É claro: toda realidade futura - afirmava Einstein em seu ensaio sobre Braque, em

* (MICHAUD, Éric. "La construction de l'image comme matrice de l'histoi$\mathrm{re}^{\prime \prime}$. In: Vingtième Siècle. Revue d'histoire, $\mathrm{n}^{\circ} 72$, out.dez., 2001: 41.) 
* (COCCIA, Emanuele. Filosofía de la imaginación. Averroes y el averroismo. Estudio preliminar Giorgio Agamben. Trad. M.T. D'Meza. Buenos Aires, Adriana Hidalgo, 2007.)

* (MICHAUD, Éric. op. cit.: 52.)
1932 - começa e se ativa sob forma de mito, aposta que logo merece a restrição iluminista de Michaud, que confunde Einstein com um mero comparsa de Hitler. Evidentemente, Michaud não consegue reconhecer, em Einstein, a reivindicação de uma autêntica máquina mitológica, vazia em seu interior, à maneira de Furio Jesi e, por essa via, de seus discípulos, Giorgio Agamben ou Emanuele Coccia.* $\mathrm{E}$ a constatação da imagem como um processo desencarnado simplesmente augura, aos olhos de Michaud, uma lamentável desumanização da arte, não muito distante da reprovação elitista de Ortega y Gasset.

De cette désincarnation sont résultés, dans le champ politique, une infigurabilité du lieu du pouvoir et un vide inappropriable que l'on peut entendre retentir dans la phrase fameuse de Michelet : "La Révolution a pour monument... le vide...". Et l'on sait que l'exigence démocratique veille à préserver ce vide ou ce non-lieu qui lui est essentiel, puisqu'il génère la division et le conflit constitutifs de l'espace propre à la démocratie.*

Ora, é bom relembrar, entretanto, que uma imagem não é matéria de uma percepção (o que vemos), nem mesmo um ideal sensível (o duplo das coisas construído por nosso espírito). As imagens são coisas. Elas são mesmo a Coisa. Mas, além do mais, elas são um método, una passagem, à maneira benjaminiana ou ainda, como diria Deleuze, o caminho por onde passam, de certo modo, todas as mudanças que se preservam na imensidade do universo. As imagens são, portanto, a história. Quando, a partir delas, conseguimos construir uma linguagem, esse discurso denomina uma arte (no sentido que lhe dá Thierry de Duve: uma ausência), mas ele denomina também uma história (e até mesmo sua presença).

Quem melhor e mais profundas consequências tem retirado dessa potência das imagens no cenário contemporâneo é outro francês, Georges Didi-Huberman. Não apenas em sua obra de crítico e historiador, ${ }^{1}$ mas também como curador da exposição Atlas.

${ }^{1}$ Cf. DIDI HUBERMAN, Georges "L'immagine aperta" in RISSET, Jacqueline (ed.) Georges Bataille: il Politico e il Sacro. Napoli, Liguori, 1987, p.167-188; Idem. La ressemblance informe. Ou le gai savoir visuel selon Georges Bataille. Paris, Macula, 1995; Idem. L'image survivante. Histoire de l'art et temps des fantômes selon Aby Warburg. Paris, Les Éditions de Minuit, 2002; Idem. Ninfa moderna. Essai sur le drapé tombé. Paris, Gallimard, 2002; Idem. "O anacronismo fabrica a história: sobre a inatualidade de Carl Einstein", trad. M. Ozomar Ramos Squeff in ZIELINSKY, M. (ed). Fronteiras. Arte, crítica e outros ensaios. Porto Alegre, Editora da Universidade Federal do Rio Grande do Sul, 2003, p. 19 53; Idem. Imágenes pese a todo: memoria visual del holocausto, Barcelona, Paidós, 
Como carregar o mundo nas costas? (Museo Nacional Reina Sofia, Madri, 2010-2011), Didi-Huberman tenta atualizar a iconologia dos intervalos, inventada e teorizada pelo crítico alemão Aby Warburg, no sentido de uma "ciência nômade" ou "excêntrica", ou ainda "menor", tal como Deleuze e Guattari a propuseram em Mil platôs, saber esse sempre confrontado, de maneira intransigente, a uma "ciência real" ou "ciência de Estado". O trabalho do curador, mero encenador metodológico das hipóteses críticas do historiador da arte, constitui portanto um saber problemático, mas não necessariamente axiomático, baseado sempre em modelos de devir e de heterogeneidade, que se opõem assim ao estável, o eterno, o idêntico e ao que é constante e permanente.*

Não apenas como concessão localista a um artista nacional, mas por encontrar nele profundos estímulos para uma variabilidade incessante, Didi-Huberman apoia-se fartamente, dessa vez, não só nas gravuras e nos escritos de Francisco de Goya, mas no aproveitamento que deles tira Baudelaire, operação com a qual Didi-Huberman desloca o etnocentrismo de uma teoria da modernidade exclusivamente autonomista. Longe de ver as aparentes contradições de Goya como hesitações inseguras, em busca de estabilização dialética, Didi-Huberman resgata seu notável conceito de imaginação (fantasia), em torno do qual Goya constrói sua teoria da arte.

La imaginación sería de algún modo el pharmakon de Goya: ella es efectivamente ese "lenguaje universal" que sirve para todo, para lo peor y para lo mejor, para lo peor de los monstra tanto como para lo mejor de los astra. La imaginación abandonada a sí misma, eso es lo peor: "produce [entonces] monstruos imposibles", y deja proliferar las "extravagancias y desaciertos" de una "sociedad civil" en manos de "la ignorancia o el interés". ¿Qué hacer para acometer su crítica?

2004; Idem. Venus rajada: desnudez, sueño, crueldad. Madrid, Losada, 2005; Idem. Ante el tiempo. Historia del arte y anacronismo de las imágenes. Buenos Aires, Adriana Hidalgo, 2006; Idem. L'image ouverte. Motifs de l'incarnation dans les arts visuels. Paris, Gallimard, 2007; Idem. La invención de la histeria. Charcot y la iconografía fotográfica de la Salpêtrière. Trad. Tania Arias y Rafael Jackson. Madrid, Cátedra, 2007; Idem. "La emoción no dice yo. Diez fragmentos sobre la libertad estética" in JAAR, Alfredo et al. La politica de las imágenes. Santiago de Chile, Metales Pesados, 2008; Idem. La ressemblance par contact. Archéologie, anachronisme et modernité de l'empreinte. Paris, Les Éditions de Minuit, 2008; Idem. Ser cráneo. Lugar, contacto, pensamiento, escultura. Trad. Rosario Ibañes. Madrid, cuatro ediciones, 2009; Idem. Survivance des Lucioles. Paris, Les Éditions de Minuit, 2009; Idem. Remontages du temps subi. Paris, Les Éditions de Minuit, 2010; ZIMMERMANN, Laurent (org.). Penser par les images. Autor des travaux de Georges Didi-Huberman. Nantes, Éditions Cécile Defaut, 2006.
*(DIDI-HUBERMAN, Georges. Atlas ¿Cómo llevar el mundo a cuestas? Trad. Maria Dolores Aguilera. Madrid, Museo Nacional Centro de Arte Reina Sofia, 2010: 52.) 
Censurarla es precisamente lo que trata de hacer la Inquisición: resulta injusto e inoperante, un oscurantismo contra otro. De todos modos, antropológicamente hablando, nadie podría "suprimir" las imágenes o la imaginación, la cual conforma por completo al hombre. Por consiguiente, será preciso ocupar tan peligroso terreno y convocar a la imaginación con la razón, su falsa enemiga. El arte designaría entonces el lugar donde esa doble convocatoria resulta posible: “Unida con la razón, [la fantasía] es madre de las artes”. He aquí por qué - y se trata de un elemento capital del razonamiento de Goya - la pintura puede tener como objeto la "censura de los errores" humanos. Una crítica en el sentido de Kant, si se quiere, y que convierte la pintura, a juicio de Goya, en una actividad filosófica que apunta a lo "universal” (...). En suma, no se revoca la imaginación: tenemos que portarla - como Atlas porta el cielo para convertirse en su experto por antonomasia - y reportarla a una mesa de trabajo o una lámina de grabado. Lo cual se lleva a cabo a partir de una opción razonada, una "combinación" que designa ya el "artificio" figurativo más importante como un montaje de cosas diversas y confusas que, "ingeniosamente dispuestas", permiten que una imagen pintada o grabada alcance lo universal. Los "monstruos" de Goya nada tienen en absoluto del desahogo personal, sentimental o frívolo que sugeriría una mala lectura de la palabra fantasía: son obra de un artista que entendía su trabajo como una "antropología del punto de vista de la imagen”, o sea, una reflexión que toma su método de su objeto, la imaginación pensada como herramienta - idónea, técnicamente elaborada, filosóficamente construida - de un auténtico conocimiento crítico del cuerpo y el espíritu humanos. Este es, pues, el arte pensado por Goya como una verdadera crítica filosófica del mundo y, de modo particular, de esa "sociedad civil" a la que se refiere en el Diario de Madrid. Para asumir tamaño reto, convendrá actuar dialécticamente en dos frentes a la vez: por su actividad crítica, el artista ha de proceder a justos encuadres de la realidad que observa y, por ende, de esa verdad de la que desea dar testimonio; por su actividad estética, se toma la libertad, la fantasía, de proceder a montajes entre las cosas más dispares.*

A posição vale como um acerto de contas com a escola inglesa de discípulos de Warburg, pois enquanto Panofsky faz o discurso crítico repousar nas constantes do compars, o Warburg deleuziano, de Didi-Huberman, e mesmo esse Baudelaire goyesco-nietzschiano que ele nos propõe em Atlas, encontram, na chave do dispars, dos desastres e disparates da guerra, o modo de relacionar imagem e história. Surge, assim, dessa operação à la Godard, um outro Baudelaire, nem fenomenológico, como o de Sartre, nem pós-moderno, como o de Jameson. 
Baudelaire insiste [...] en la constante paradoja de las composiciones de Goya, entregadas siempre a la fantasía de los contrates: lo "cómico" en él es "pavoroso", la "sátira", "espanto"; la "faz bestial", "humanidad" por antonomasia... Pero tales paradojas nada serían sin la necesidad fundamental que las sostiene y que, propone Baudelaire, sólo puede comprenderse en relación con un auténtico saber de las leyes de la historia natural, cuando Goya se revela capaz de mostrarnos monstruos "viables" o "verosímiles". ¿Qué significa ello sino que el gran artista se distingue por su capacidad para conjuntar lo "transcendente" y lo "natural", lo "fantástico" y lo "real”? ¿No reconocemos aquí, exactamente formulada, la definición baudeleriana de la imaginación que, más allá de cualquier fantasía gratuita o personal, se vuelve capaz de sacar a la luz las "líneas de sutura" o los "puntos de confluencia" entre cosas que todo parece oponer - risa y angustia, humanidad y animalidad, rostro exterior y espectro interior -, una percepción de las "relaciones íntimas y secretas de las cosas”, que el erudito, y no sólo el poeta, no podrá ahorrarse? Baudelaire lo condensa magníficamente, a propósito de Goya, al proponer que veamos en esos hervideros de figuras algo semejante a rigurosas "muestra[s] del caos".*

* (Ibidem: 93.)

Em consequência, Didi-Huberman trabalha a história como uma arqueologia da sensibilidade e, nesse ponto, imita o gesto de uma certa vanguarda, com os atlas de Bertold Brecht, Marcel Broodthaers ou Gerhard Richter, as montagens de El Lissitsky ou Robert Rauschenberg, as esculturas involuntárias de Brassaï e Breton. O objetivo é, quase mimetizando a lógica de funcionamento das tablets, para as quais é indiferente o funcionamento horizontal ou vertical, desmanchar uma cristalização do quadro (tableau), como efeito autônomo da ação do artista e, projetando-o na horizontalidade, ver nele apenas uma mesa (table), onde as operações de montagem do crítico possam fazer tabula rasa de dois princípios cruciais do autonomismo: a unidade visual e a imobilização temporal. A ideia é, portanto, recuperar espaços e tempos heterogêneos que não cessam de se encontrar, de se confrontar, de se cruzar, ou até mesmo de se amalgamar. Assim como o quadro é formalmente considerado como uma obra, um efeito quase residual, em que tudo já foi previamente consumado, a mesa, pelo contrário, seria um dispositivo (Foucault, Agamben) em que tudo pode ainda vir a começar, sempre. A mesa é um campo operatório do díspar e do móvel, do heterogêneo e do aberto. Seu antecedente epistemológico, o Bilderatlas warburguiano, graças a seu dispositivo de mesa de montagem sempre modificável, permitia-lhe ao crítico multiplicar, afinar ou bifurcar as noções concernentes à grande sobredetermina- 
* (BORGES, Jorge Luis. "El idioma analítico de John Wilkins". In: Obra Completa. Buenos Aires, Emecé, 1974: 706-9) ção das imagens, que a psicanálise tornara irrefutáveis, e até mesmo diagnósticas, com Rorschach.

Embaralhar e repartir as cartas, desmontar e remontar a ordem das imagens, numa mesa operatória, a fim de configurar afinidades quase divinatórias, capazes de entrever o trabalho do tempo no mundo visível: eis o que Didi-Huberman denomina atlas. O conceito apoia-se, além do mais, no de uma certa "enciclopédia chinesa", a de Borges, * revisitada por Foucault, onde os animais estão disparatadamente clasificados em: a) pertencentes ao imperador, b) embalsamados, c) amestrados, d) leitões, e) sereias, f) fabulosos, g) cães soltos, h) incluídos nesta classificação, i) que se agitam como loucos, $\mathrm{j}$ ) inumeráveis, $\mathrm{k}$ ) desenhados com um pincel finíssimo de pêlo de camelo, l) et cetera, m) que acabam de quebrar o jarro, n) que de longe parecem moscas.... E dessa enumeração caótica extrai Foucault os elementos para postular a episteme ocidental, aquela que regula as relações entre as palavras e as coisas. Para Didi-Huberman, entretanto, a mesa de Borges, tal como "O quadro", o poema de Murilo Mendes que lê a aliança dos Arnolfini segundo van Eyck, não aposta apenas à moldura de um quadro que organizaria per se a quadrícula e a malícia perspectivistas. Antes, pelo contrário, ela evoca certas compilações de desenhos chineses ou de estampas japonesas, como as de Hokusai, quebrando os parâmetros classificatórios ocidentais. Se, de um lado, esse procedimento arruína o quadro ou, o que é o mesmo, o sistema costumeiro dos saberes, por outra, ele também libera, satiricamente, um riso capaz de suscitar o mal-estar cultural, uma vez que ele provém de um fundo enigmático de não saber: o Real.

Tanto Borges quanto sua irmã, a artista plástica Norah Borges, elaboraram, em 1928, o ano de Rua de mão única, uma mesa de operações imaginárias onde também se sobrepunham objetos disparatados que se integravam na esfera do Heimlich: uma cuia para chimarrão, de prata, com um passarinho de arremate, mangedouras de gesso policromado, títeres vestidos de tarlatana, quadros de Picasso, fotografias antigas, de 1880, ou álbuns de moda de 1860, gravuras de cores vivas, em decalcomania, no melhor estilo Paulo e Virginia, estampas de moças jovens, ornadas com chapéus de palha da Itália, como no filme de Renoir, e muitas guirlandas de flores, tal como numa paisagem das Antilhas.

Aparecen los frescos de La Historía de Herodes de Masolino, los cuadros de Abrahan Angel y de los niños mejicanos, los altares de 
las iglesias de Portugal, los abanicos isabelinos donde está pintado un niño jugando al aro, los cuadros de Pruna y sus dibujos para decoraciones de teatro, las cajitas de música, con una sola pieza, los herbarios y las colecciones de mariposas, los gráficos de Santa Rosa de Lima, con corazones y palomas, las casas blancas de Le Corbusier, los cuadros celestes y rosados de Irene Lagut, las casas de Buenos Aires con alegorías de yeso, las manos de bronce de los llamadores, los carritos de los panaderos que tienen pintados pájaros y manos entrelazadas con una rosa, la ropa de lentejuelas de los acróbatas, los trajes de luces y las medias rosadas de los toreros y hasta los globos terrestres de cartón con el delicioso celeste de los mares. ${ }^{2 *}$

Ora, essa autoridade abalada, que fixa, justamente, a forma das relações entre coisas vistas e palavras enunciadas, fez do quadro (da obra) um espaço para ver o que podemos dizer, mas onde não poderíamos dizer nem mesmo ver a distância entre objetos e linguagem. Daí que, logo no início de As palavras e as coisas, Foucault denomine a mesa de Borges como um "atlas do impossível", uma heterotopia que não é senão a desordem cotidiana que faz cintilar os fragmentos de um número infinito de ordens possíveis, na dimensão aleatória do heteróclito, espaço de crise e desvio, caprichoso ordenamento de lugares incompatíveis e tempos heterogêneos, somente ativados por dispositivos socialmente separados, mas facilmente penetráveis. Em suma, máquinas concretas de imaginação, que criam um espaço de ilusão que denuncia o real como um espaço ainda mais ilusório do que o próprio espaço da fantasia mais recalcitrante. Nessa perspectiva de descompartimentalização, o atlas borgiano-foucaultiano, de que Didi-Huberman se vale, funciona como um campo operatório capaz de pôr em prática, tanto epistêmica quanto estética, e até mesmo politicamente, uma impugnação tão mítica quanto real do espaço em que se processa nossa imaginação política.

\section{Destino e distanciamento}

Essas hipóteses de Didi-Huberman sustentam também uma outra exposição que lhe é contemporânea, Imágenes e Historias. Argentina 1848-2010, curada por Diana Wechsler, apresentada de início em Madri (Fundação MAPFRE, 2010) e exibida, entre março e abril de 2011, no Centro Cultural Recoleta de Buenos Aires. Po-

\footnotetext{
${ }^{2}$ Trata-se de uma lista semelhante àquela que Lichtemberg elabora, à maneira de Swift, e publicada no almanaque de Gotinguen em 1798, ou àquela que Wolgang Paalen publica, em 1939, na revista Minotaure.
}

* (BORGES, Norah. "Nueve dibujos y una confesión: Lista de las obras de arte que prefiero". La Nación (12 ago 1928) apud ARTUNDO, Patricia. Norah Borges. Obra Gráfica 1920-1930. Buenos Aires, s.c.p.:157.) 
deríamos até pensar que Wechsler começa onde Didi-Huberman termina. Em parte, porque os desastres da guerra de Goya são fruto da invasão napoleônica que, por sua vez, detona o processo emancipatório latino-americano. Mas, em parte também, porque a leitura de Didi-Huberman ainda padece de uma certa estreiteza, na medida em que da América Latina vê tão somente a arte pré-colombiana, e tal como a etnografia, notadamente francesa, conseguiu captá-la. Ou, quando muito, estimulando um salto conceitual vanguardista, de que o melhor exemplo é ainda Josef Albers, que não vai muito além da dimensão verbivocovisual do concretismo. Pelo contrário, a exposição de Wechsler trabalha, paradoxalmente, com o processo da autonomia nacional, em clara fase de anautonomia estética. Assim, nas salas J e C do Centro Recoleta, sob o rótulo de "Historia política, dissenso estético", a epígrafe da mostra é uma encenação do conflito étnico, sublimado em um relato como "O cativo" de Borges, ${ }^{3}$ mas aqui restituído, com mínima violentação, à sua pungência originária, através do díptico de Res, O cacique Linares e seus descendentes (1996). Outro tanto verifica-se na foto documental da rendição de uma tribo, obtida por Antonio Pozzo, em 1879, ou no conjunto de índios chaquenhos, captados por Samuel Rimathé em 1893, associadas à imagem de um adolescente toba, de Daniel Muchiut, de 1993.

Mas é na fotografia catalogada com o no 236 que Wechsler decide instalar-se para dar coerência a seu relato curatorial. ${ }^{4}$ Eis o vórtice. Trata-se de uma fotografia de 2004, que registra a ordem, impartida por Kirchner, presidente da Argentina, para o general Roberto Bendini, comandante do Exército, para retirar o retrato de Videla da galeria de militares, nas paredes do Colégio Militar. O gesto, embora político, é também estésico, afeta sensibilidades e complementa, por exemplo, o de Gerhard Richter em Quarenta e oito retratos (1972), panteão do saber ocidental do após-guerra, acolhido em Atlas. Wechsler pondera que, embora a imagem da retirada do retrato de Videla seja histórica, porque capta a força performática da democracia, 28 anos após o golpe de estado, ela carrega também diversas temporalidades: aquela em que se iniciou a tradição de integrar o retrato dos chefes militares na galeria das

${ }^{3}$ BORGES, Jorge Luis. "El cautivo". Obras Completas. op. cit.: 788.

${ }^{4}$ Cf. Vários autores. Historia de la Argentina a través de la fotografía, Madrid, Mapfre, 2011: 289. O setor fotográfico da exposição esteve aos cuidados de Felicitas Luna, Gabriela de Antueno e Gabriel Díaz, apoiados num relato histórico construído por uma equipe de pesquisadores dirigidos por Jorge Gelman. 
"personagens ilustres", associada a uma outra anterior, a dos bustos em mármore dos presidentes, no palácio do governo, remontando, ainda, a outras mais remotas, como a dos retratos dos reis ou papas, a série do pan-theon, tentando criar uma espécie de elenco visual que garanta a continuidade de um regime político que descansa na hipótese de replicar-se a si próprio, infinitamente. São todos exemplos da relevância revolucionária das efígies, bem documentadas, quanto à França, no Museo Carnavalet.

Laura Malosetti Costa, visando também desnaturalizar a função mimética mais evidente dos retratos de proceridade militar, que acompanharam o processo de guerras pela independência na América Hispânica, vem trabalhando com a obra do pintor peruano José Gil de Castro (1785-1837), um artista mulato que retratou, amplamente, os líderes revolucionários da época, José de San Martín, Simón Bolívar, Bernardo O’Higgins, e em cuja obra, segundo Malosetti, mais do que a referencialidade, interessa, basicamente, a opacidade desses retratos, pintados, muitas vezes, palimpsestuosamente, sobre outros retratos prévios, que a Revolução tornava caducos: os retratos do rei. Os próceres eram aí representados jovens, com atributos épicos, mas também com emblemas intelectuais, uma vez que lideravam uma transformação cultural profunda. Mais tarde, quando tivessem 60 anos, seriam novamente representados pela incipiente fotografia, que delataria a impropriedade de fardas excessivamente apertadas para silhuetas um pouco roliças ou nem tão brilhantes como as estratégias do óleo queriam fazer-nos crer.

El daguerrotipo aparece anclado en un momento preciso, en el que el dispositivo fotográfico irrumpía con enorme fuerza en el campo de actividad de los retratistas, pero sobre todo de los miniaturistas. El retrato no fue considerado entre los géneros "mayores" de la pintura dentro de las jerarquías académicas, en tanto la exigencia del parecido restringía al máximo las posibilidades de invención de los pintores. En el retrato, aquéllos debían ser, ante todo, fieles a la naturaleza, ya que la imagen debía hablar a los sentidos antes que a la inteligencia: la definición última del retrato era (es) el reconocimiento de un individuo, su evocación por medios visuales. Y si bien no siempre fue el parecido el parámetro de tal evocación, sí lo fue, indudablemente, en el siglo XIX, cuando el deseo de capturar una "verdad" y sus fantasmas en la imagen dio por resultado una proliferación de invenciones técnicas para lograrlo. De modo que no fue tanto la creatividad del artista sino más bien su habilidad para lograr la semejanza con el modelo aquello que se valoró más 
en relación con el retrato, pero sobre todo con los usos privados del género. Es decir: en aquellos retratos en los que, más allá o más acá de los símbolos exteriores desplegados en las ropas o accesorios que las enmarcan y connotan, efectivamente, lo esencial era el parecido en las facciones, condición ineludible para lograr ser soporte de la vanidad o del recuerdo de los seres queridos y sobre todo de los muertos. $^{5}$

Da mesma forma, em Imagens e histórias, Wechsler repõe o caráter heteróclito das imagens e monta com elas séries diversas, tais como a "fotografia documental", de arquivo público, junto a obras pictóricas ou plásticas, inegavelmente inscritas no espaço autônomo da arte, assinadas por Emilio Pettoruti, Xul Solar, Juan Del Prete, Raul Lozza, Lidy Pratti ou Enio Iommi, contemporâneas da emergência das massas, ou de Julio Le Parc, Martha Botto, León Ferrari e Margarita Pacsa, mais recentemente, bem como um conjunto de instalações e intervenções - site specifics - como o emblemático Sin pan y sin trabajo, de Della Carcova, relido por Tomás Espina em SpSt (2002), até aquilo que se define como "fotografia contemporânea", em artistas como Jorge Macchi, Graciela Sacco, Gabriela Golder, Carlos Trilnik, Mariano Molina, Matilde Marín, Res, Marcos López, Adriana Lestido ou Facundo de Zuviría. Wechsler está consciente de ter tomado estes tableaux em seu valor de uso e tê-los tornado tables operatórias que transformam o trabalho curatorial como um pas au-delà, tanto da tarefa do historiador quanto do trabalho do artista.

La narración histórica organiza y a la vez busca interpretar el pasado, en tanto la operación curatorial del montaje al yuxtaponer imágenes y tiempos, ensaya otros modos de relato, discontinuo, quebrado, en donde la posición relativa de cada pieza supone a su vez su resignificación. Una y otro - la narración histórica y el montaje de imágenes - ccomparten el hecho de conocer el punto de arribo de la historia dado que participan de un mismo tiempo presente desde donde se observa-analiza-seleccionan aspectos del pasado, sin embargo, en tanto la historia necesita de ciertas estructuras narrativas que le den continuidad y la hagan legible, el montaje plantea la puesta en común de diferentes imágenes, pero una puesta que deja inevitablemente espacios, intersticios entre unas y otras imágenes que son las que invitan al espectador a completar desde su perspectiva, con su mirada - una mirada cultural, poblada de saberes que son los

\footnotetext{
${ }^{5}$ COSTA, Laura Malosetti. "¿Verdad o belleza? Pintura, fotografía, memoria, historia”. Revista Crítica Cultural, vol. 4, n 2, UNISUL, Florianópolis, set. 2010: 113 .
} 
que la constituyen - un relato posible, en donde se expanden los sentidos, más allá de una narración conclusa. ${ }^{6}$

Wechsler apoia-se, para tanto, nas ideias de Jacques Rancière, em Le destin des images, quando, a partir das Histoire(s) de Jean-Luc Godard, Rancière distingue dois tipos de montagens, a dialética e a simbolista. ${ }^{7} \mathrm{O}$ resultado dessa montagem dialética é conceber a montagem como uma máquina que insere a heterogeneidade no espaço, dando-lhe especial relevo, quase atribuindo-lhe a responsabilidade de uma quarta dimensão para assim estimular associações impensadas, analogias fortuitas e até mesmo fortes dissonâncias na recepção. Até mesmo quando, na fundamentação de Ima-

${ }^{6}$ WECHSLER, Diana B. "Imágenes e historias". In: Imágenes e historias. Argentina 1848-2010. Fotografía documental y artes visuales. Catálogo da exposição. Centro Cultural Recoleta, Buenos Aires, mar 2011:14.

7 "La manière dialectique investit la puissance chaotique dans la création de petites machineries de l'hétérogène. En fragmentant des continus et en éloignant des termes qui s'appellent, ou, à l'inverse, en rapprochant des hétérogènes et en associant des incompatibles, elle crée des chocs. Et elle fait des chocs ainsi élaborés de petits instruments de mesure, propres à faire apparaitre une puissance de communauté disruptive, qui impose elle-même une autre mesure. Cette petite machinerie, ce peut être la rencontre de la machine á coudre et du parapluie sur une table de dissection, ou bien des cannes et des sirènes du Rhin dans la vitrine désuète du Passage de l'Opéra, ou encore de tous autres équivalents de ces accessoires dans la poésie, la peinture ou le cinéma surréalistes. La rencontre des incompatibles y met en évidence le pouvoir d'une autre communauté imposant une autre mesure, elle impose la réalité absolue du désir et du rêve. Mais ce peut être aussi le photo-montage militant à la John Heartfield qui fait apparaître l'or capitaliste dans le gosier d'Adolf Hitler, c'est-à-dire la réalité de la domination économique derrière le lyrisme de la révolution nationale, ou, quarante ans plus tard, celui de Martha Rosler qui «transporte à domicile » la guerre vietnamienne en mélangeant ses images avec celles des publicités pour le bonheur domestique américain. Ce peut être, plus près de nous encore les images de homeless que Krzystof Wodiczko projette sur les monuments officiels américains ou les tableaux que Hans Haacke accompagne de petites notices indiquant les sommes qu'ils ont coûtées à chacun de leurs acheteurs successifs. Dans tous ces cas, il s'agit de faire apparaître un monde derrière un autre : le conflit lointain derrière le confort du home, les homeless expulsés par la rénovation urbaine derrière les buildings neufs et les emblèmes anciens de la cité, l'or de l'exploitation derrière les rhétoriques de la communauté ou les sublimités de l'art, la communauté du capital derrière toutes les séparations de domaines et la guerre des classes derrière toutes les communautés. Il s'agit d'organiser un choc, de mettre en scène une étrangeté du familier, pour faire apparaître un autre ordre de mesure qui ne se découvre que par la violence d'un conflit. La puissance de la phrase-image qui joint les hétérogènes est alors celle de l'écart et du heurt qui révèle le secret d'un monde, c'est-à-dire l'autre monde dont la loi s'impose derrière ses apparences anodines ou glorieuses." RANCIÈRE, Jacques. Le destin des images. Paris, La Fabrique, 2003 : 66-67. 
gens e histórias, se invocam certas categorias da Teoria Estética de Adorno, elas aparecem filtradas pelo crivo da incontornável cisão do sujeito. Com efeito, Adorno argumentava que, nos artistas de altíssima classe, categoria que, em última análise, a própria exposição põe em crise, aliava-se a mais aguda consciência da realidade junto a mais completa alienação da realidade, o que por si mesmo constituía objeto digno da psicologia da arte, que não teria de decifrar a obra apenas como algo de semelhante ao artista, mas como alguma coisa de diferente, como trabalho em torno de algo que, precisamente, resiste à interpretação. Se a arte tem raízes psicanalíticas, dizia Adorno, elas são as da fantasia de onipotência, aquilo que, com Jacques-Alain Miller (e com o dadaísmo e até mesmo com Valéry), chamaríamos de a salvação pelo dejeto. $\mathrm{Na}$ arte, onde sempre atua o desejo de construir um mundo melhor, libertando assim a dialética total, deparamo-nos também com um conceito de obra de arte que a linguagem puramente subjetiva do inconsciente não consegue por si só apreender. É preciso a ela acrescentar uma abordagem filológica, antropológica e até mesmo política, mas não necessariamente ideológica.

Uma das imagens de Adriana Bustos, Objets in mirror are closer than they appear (2005), que é uma retrovisão através da janela posterior de um automóvel em movimento, nos ilustra um aspecto dos procedimentos expositivos de Imagens e histórias. Compõe a montagem de Wechsler uma foto de 1905, de três moças, sentadas em um jardim, com seus vestidos alvos, de rendas e bordados. A rua era então vedada às sinhazinhas de família e respira-se concretamente, no retrato, uma pátina século XIX. Ao lado desta, temos a foto de três outras moças, de tailleur, salto alto e chapéu, saindo do metrô, na Praça Itália, em 1942, tendo, ao fundo, a estátua equestre de Garibaldi. Por último, outras três jovens, caracteristicamente universitárias, se agitam na rua, vestindo minissaias, em 1969. De repente, um dado externo, completou, a meu ver, a cena, porque, junto comigo, percorriam a sala do museu três rapazes. Um deles, com camiseta regata preta, ostentava um tapiz de tatuagens em sua anatomia body-builded. O segundo tinha bermudas bastante estrambóticas e sandálias havaianas. $\mathrm{O}$ terceiro cobria a cabeça com um boné. Não eram turistas. As três graças já não apareciam numa réplica de Canova, como aquelas que Sarmiento quis espalhar pela cidade, nem eram mesmo mulheres, mas adquiriam a feição fantasmática de nós mesmos. 
Como no mural All over the wall (2010-2011), de Mariano Molina, que nos acolhera no salão principal da exposição, o próprio público reatava, assim, o paradoxo das imagens com relação aos acontecimentos, através dos recursos de apropriação das peças do passado, do isolamento, mas também da exibição de outras imagens que, por serem tão cotidianas, tornaram-se invisíveis, tal como em Reocupação. A memória do corpo (2006-2011), a videoinstalação de Gabriela Golder com anônimos que, sem trabalho, repetiam o fantasma de uma rotina, há anos automatizada. Ou como na escultura $O$ mar que o traz (2006), de Mariana Schapiro, que nos remete à utopia imigratória em El Dorado, mas não menos aos famigerados voos da morte, sob a ditadura, mas, em todo caso, a ideia de que a imagem (a Coisa) sempre retorna. Como conclui Wechsler, "en unos la distancia, en otros la mostración, en todos, la voluntad de una política del arte, centrada en el entrelazamiento de lógicas heterogéneas".

\footnotetext{
${ }^{8}$ RANCIÈRE, Jacques. "Las paradojas del arte político". In: El espectador emancipado. Trad. A. Dillon. Buenos Aires, Manantial, 2010: 52-84. Para Rancière, os universos de percepção contemporâneos já não compreendem os mesmos objetos pensados pelas vanguardas, nem pressupõem os mesmos sujeitos, muito mais crivados e divididos, assim como também não funcionam mais as mesmas regras, o que abre possibilidades inéditas para a relação entre arte e política. A seu ver, os processos de emancipação operativos hoje são aqueles que tornam as pessoas capazes de inventar práticas que não existiam ainda. Em entrevista reproduzida pela revista Urdimento ( $\mathrm{n}^{\circ}$ 15, Florianópolis, UDESC, out. 2010: 123-33) Rancière afirma: "A estética e a política são maneiras de organizar o sensível: de dar a entender, de dar a ver, de construir a visibilidade e a inteligibilidade dos acontecimentos. Para mim, é um dado permanente. É diferente da ideia benjaminiana de que o exercício do poder teria se estetizado num momento específico. Benjamin é sensível às formas e manifestações do Terceiro Reich, mas é preciso dizer que o poder sempre funcionou com manifestações espetaculares, seja na Grécia clássica, seja nas monarquias modernas. Há um momento em que é preciso distinguir duas coisas: de um lado, a adoção de certas formas espetaculares de mise-en-scène do poder e da comunidade. De outro, a ideia mesma de comunidade. É preciso saber se pensamos a comunidade política simplesmente como um grupo de indivíduos governados por um poder ou se a pensamos como um organismo animado. Na imaginação das comunidades há sempre esse jogo, essa oscilação entre a representação jurídica e uma representação estética. Mas não creio que se possa definir um momento preciso de estetização da comunidade. Por exemplo, o nazismo, que é usado frequentemente como exemplo de política estetizada, na verdade também recuperou a estética de seu tempo. Pense nas demonstrações dos grupos de ginástica em Praga nos anos 1930. Eram associaçôes apolíticas ou absolutamente democráticas, com a mesma estética que encontramos no nazismo. Para mim, é preciso tomar distância da ideia de um momento totalitário da história marcado especialmente pela estetização política, como se pudéssemos inscrever isso num momento de anti-história das formas estéticas da política e das formas de espetacularização do poder.”
} 
Didi-Huberman se propôs trabalhar a história como arqueologia e, para tanto, incluiu, em Atlas, um princípio de indeterminação e abertura, ${ }^{9}$ visível, por exemplo, nas sombras e fumaças de Alfred Stieglitz e nos trabalhos de Sigmar Polke, Charles Ross ou Thomas Ruff. Coincidentemente, Diana Wechsler fecha o circuito de Imagens e histórias com duas enormes fotografias de Matilde Marin, Itinerário em direção ao vento e Itinerário em direção à nuvem (2006), que funcionam como colofão da série. Ambas confirmam a ideia que Walter Benjamin registra em seu ensaio sobre Kafka: sopra uma tormenta a partir do esquecimento. Estudar é cavalgar contra ela.

\section{Raúl Antelo}

É professor titular de literatura brasileira na Universidade Federal de Santa Catarina. Pesquisador-sênior do CNPq, foi Guggenheim Fellow e professor visitante nas Universidades de Yale, Duke, Texas at Austin, Autónoma de Barcelona e Leiden, na Holanda. Presidiu a Associação Brasileira de Literatura Comparada (Abralic). É autor de vários livros, dentre os mais recentes, Transgressão \& Modernidade; Potências da imagem; Crítica acéfala; Ausências; Maria com Marcel. Duchamp nos trópicos e Alfred Métraux: antropofagia e

${ }_{9}^{9}$ Podemos associar esse intervalo ao conceito pictural, plástico, de nuvem, não necessariamente fundido a seu valor icônico. Damisch esclarece: "Entre le / nuage / em peinture et le nuage 'réel', le rapport n'est d'abord que d'homonymie, au sens où l'entend Aristote dans le traité des Catégories: 'On appelle homonymes les choses dont le nom seul est commun, tandis que la notion désignée par ce nom est diverse. Par exemple, animal est aussi bien un homme réel qu'un homme en peinture ; ces deux choses n'ont en effet en commun que le nom, alors que la notion désignée par le nom est différente' (Cat., I, cité par Bernard Pautrat, Versions du soleil, figures et système de Nietzsche, Paris, Ed. du Seuil, 1971: 13-14, n.1.) C'est dire, comme on aura à y insister, que les occurrences du motif / nuage / doivent être considérées en termes sémiologiques, avant toute référence à la réalité dépeinte, phénomène physique ou objet matériel. [...] Car si le / nuage/, considéré en tant que graphe pictural, peut paraître contredire aux données et aux principes d'un art fondé sur la stricte délinéation des formes et la perspective géométrique, s'il permet en outre de soustraire les figures aux lois de la physique des corps et autorise nombre d'effets aériens, de transports, de ruptures et de juxtapositions paradoxales, ce n'est pas à dire que son occurrence, son maniement, son traitement même relèvent du seul caprice, de la 'manière' au sens péjoratif du mot. L' " ivresse " à laquelle convie le Corrège est précisément calculée, et le nuage entre dans ce calcul à titre de vecteur libre qui prête à des opérations dont Burckhardt a parfaitement reconnu la nature sémiotique, tout à la fois signalétique et syntaxique. Le / nuage / n'est pas seulement le moyen d'un style, mais le matériau d'une construction." DAMISCH, Hubert. Théorie du nuage. Pour une histoire de la peinture. Paris, Seuil, $1972: 27-9$. 
cultura. Editou $A$ alma encantadora das ruas de João do Rio; Ronda das Américas de Jorge Amado; Antonio Candido y los estudios latinoamericanos e Argentina: texto, tempo, movimento.

\section{Resumo}

Este artigo aborda duas exposições, Atlas. Como llevar el mundo a cuestas?, cujo curador foi Georges Didi-Huberman e Imágenes e Historias. Argentina 1848-2010, curada por Diana Wechsler. Ambas consideram a produção artística como fruto de montagem, em que objetos, espaços e tempos podem ser reconfigurados. Ambas também encaram a experiência da imagem com base não na ordem cronológica e logocêntrica, como no historicismo clássico, mas a partir do reconhecimento da densidade de sentidos da imagem, bem como de seu poder expressivo, capaz de desestabilizar paradigmas epistemológicos da história da arte.

\section{Abstract}

This paper focuses two exhibitions, Atlas. How to carry the world on one's back?, curated by Georges Didi-Huberman and Images and histories. Argentina 1848-2010, curated by Diana Wechsler. Both consider artistic production as a montage, in which things, places and time can be reconfigured. Both also approach the experience of images not on the basis of chronological and logocentric order, like in classical historicism, but rather on the basis of a recognition of images' density of meaning and expressive power capable of destabilizing the epistemological patterns of art history.

\section{Resumen}

Esta comunicación aborda dos exposiciones, Atlas. Como llevar el mundo a cuestas?, cuyo comisario fue Georges Didi-Huberman e Imágenes e Historias. Argentina 1848-2010, curada por Diana Wechsler. Ambas consideran la producción artística como fruto de montaje, en que objetos, espacios y tiempos pueden ser reconfigurados. Ambas encaran la experiencia de la imagen no en base al orden cronológico y logocéntrico, como en el historicismo clásico, sino basándose en el reconocimiento de la densidad de sentidos de la imagen y asimismo en su poder expresivo, capaz de desestabilizar paradigmas epistemológicos de la historia del arte.
Palavras-chave: anacronismo; imagem; montagem.

Keywords: anachronism; image; montage.

Palabras-chave: anacronismo; imagen; montaje. 